\title{
Chronic Nitrogen Deposition Induces Phosphorus Limitation of Aquatic, But Not Terrestrial, Decomposition
}

\author{
Kevin S. Simon, ${ }^{1 *}$ Dennis S. Anderson, ${ }^{2}$ Ivan J. Fernandez, ${ }^{3}$ and \\ Stephen A. Norton ${ }^{4}$
}

${ }^{1}$ School of Environment, The University of Auckland, Private Bag 92019, Auckland, New Zealand; ${ }^{2}$ School of Biology and Ecology, University of Maine, Orono, Maine 04473, USA; ${ }^{3}$ School of Forest Resources, University of Maine, Orono, Maine 04473, USA; ${ }^{4}$ School of Earth and Climate Sciences, University of Maine, Orono, Maine 04473, USA

\begin{abstract}
Elevated deposition of atmospheric nitrogen $(\mathrm{N})$ has shifted nutrient availability in terrestrial and aquatic habitats of ecosystems, but rarely are ecosystem processes in those components examined simultaneously. We used a multi-decadal, whole, paired watershed experiment to determine how chronic $\mathrm{N}$ enrichment with $\left(\mathrm{NH}_{4}\right)_{2} \mathrm{SO}_{4}$ alters litter decomposition in terrestrial and stream systems. We also used short-term phosphorus (P) enrichment experiments within both watersheds to determine whether chronic $\mathrm{N}$ enrichment enhances P limitation of decomposition. Leaves from $\mathrm{N}$-treated and reference watersheds were used in a reciprocal design to parse effects of altered nutrient availability in leaves and in the environment. We found divergent responses of terrestrial and stream decomposition to altered nutrient regimes. Chronic experimental $\mathrm{N}$ enrichment increased $\mathrm{N}$ and $\mathrm{P}$ concentrations in post-abscission leaves which decayed faster than leaves from the reference watershed in the terrestrial environment. Experimental $\mathrm{N}$ enrichment also did not induce $\mathrm{P}$ limitation of
\end{abstract}

Received 17 August 2021; accepted 27 January 2022

published online 2 March 2022

Supplementary Information: The online version contains supplementary material available at https://doi.org/10.1007/s10021-022-0074 3-y.

Author contributions: KS conceptualized the study and analyzed the data, KS and DA conducted the field and laboratory work; KS, DA, IF, and $\mathrm{SN}$ wrote and revised the manuscript.

*Corresponding author; e-mail: k.simon@auckland.ac.nz terrestrial decomposition. In contrast, litter decomposition rate in the two streams was not enhanced by elevated $\mathrm{N}$ in stream water or by altered leaf chemistry. Instead, chronic experimental $\mathrm{N}$ enrichment shifted decomposition in streams from co-limitation to strong P limitation. Microbial respiration and extracellular enzyme production responded to altered nutrient availability in a manner consistent with resource allocation models. Divergent responses of terrestrial and aquatic decomposition to elevated $\mathrm{N}$ deposition likely arise from differences in water bioavailability. Our work highlights the value of simultaneously considering ecosystem processes in terrestrial and aquatic systems to understand the consequences of integrated landscape processes operating on large spatial scales.

Key words: nitrogen; phosphorus; deposition; decomposition; litter; leaf; stream; terrestrial; limitation; Bear Brook Watershed Maine.

\section{HighLIGHTS}

- Elevated chronic atmospheric nitrogen deposition shifts the stoichiometric relationship between nitrogen and phosphorus in whole 
watersheds.

- Elevated atmospheric nitrogen deposition shifts decomposition from nitrogen to phosphorus limitation in streams, but not terrestrial systems.

- Phosphorus enrichment in addition to nitrogen deposition accelerated decomposition, enhanced microbial respiration and altered the stoichiometry of enzyme activity in streams.

- Water availability likely modulates responses by influencing microbial stress and nutrient availability.

\section{INTRODUCTION}

Availability of nitrogen $(\mathrm{N})$ and phosphorus $(\mathrm{P})$ can strongly limit ecosystem processes in terrestrial and aquatic systems. In temperate regions, terrestrial systems have typically been observed to be $\mathrm{N}$ limited (Vitousek and Howarth 1991), whereas aquatic systems have been considered to be $\mathrm{P}$ limited. Growing recognition of stoichiometric linkages among multiple nutrients and broader analyses of nutrient limitation have eroded these paradigms. For example, meta-analyses have shown N, P and co-limitation can be similarly prevalent in terrestrial and aquatic systems (Elser and others 2007; Vadeboncoeur 2010). These historical paradigms have led to focus on different limiting nutrients in terrestrial and aquatic systems, which are rarely considered simultaneously even though they are intimately connected, and similar processes occur within them. Explicitly considering terrestrial and aquatic habitats of ecosystems together is important, particularly in regard to landscape-scale phenomena where connections between terrestrial and aquatic systems are important (Grimm and others 2003).

The doubling of bioavailable $\mathrm{N}$ on the planet has altered many processes across terrestrial and aquatic systems and spurred considerable interest in the role of nutrient limitation in ecosystem processes (Vitousek and others 1997). Increasing $\mathrm{N}$ from human activity is a large-scale phenomenon that acts simultaneously on linked terrestrial and aquatic systems by changing the elemental stoichiometry of organic and inorganic pools of nutrients moving between land and water. These changes in nutrient availability have altered the magnitude of critical ecosystem processes such as biological productivity and decomposition (Knorr and others 2005; Thomas and others 2010). In addition, stoichiometric theory suggests that enrichment with $\mathrm{N}$ should interact with other coupled nutrients, shifting the balance of nutrient limitation and cycling rates of other elements (Perring and others 2008). For example, elevated atmospheric $\mathrm{N}$ deposition increases $\mathrm{P}$ limitation of phytoplankton in lakes (Elser and others 2009) and forest plants (Gress and others 2007). This phenomenon is not universal (Groffman and Fisk 2011; Crowley and others 2012), but few studies have explicitly addressed the issue simultaneously in linked terrestrial and aquatic contexts.

Decomposition of organic matter is a critical ecosystem process in terrestrial and aquatic systems, and there are many similarities in processes and constraints in both habitats, including sensitivity to nutrient availability (Wagener and others 1998). Decomposition in terrestrial environments can be accelerated by fertilization with $\mathrm{N}$ or $\mathrm{P}$ (Craine and others 2007). However, atmospheric N deposition can enhance, suppress or have no effect on terrestrial decomposition rates across systems (reviewed by Knorr and others 2005). Variable response to $\mathrm{N}$ enrichment has been linked to differences in $\mathrm{N}$ deposition rate, litter chemistry and suppression of taxa that produce lignin-degrading enzymes (Carreiro and others 2000). In streams, microcosm and reach-scale experiments have shown enrichment with $\mathrm{N}$ (Ferreira and others 2006) and $P$ (Elwood and others 1981) alone, and in combination (Greenwood and others 2007; Rosemond and others 2015), can accelerate decomposition rates. Stream decomposition response to atmospheric $\mathrm{N}$ deposition has received little direct attention, with few exceptions (for example, Chadwick and Huryn 2003).

The process of decomposition relies on a microbial consortium deploying a suite of enzymes that catalyze decomposition of organic matter. These enzymes acquire carbon (C), $\mathrm{N}$ and $\mathrm{P}$, and they are responsive to shifts in organic matter chemistry and environmental chemistry, particularly $\mathrm{N}$ and $\mathrm{P}$ (Allison and Vitousek 2005). Because production of these enzymes is resource intensive, there are trade-offs in resource allocation toward enzymes that acquire $\mathrm{C}, \mathrm{N}$ and $\mathrm{P}$ (Sinsabaugh and Moorhead 1994); the balance of enzyme production reflects the underlying microbial and environmental stoichiometry (Sinsabaugh and others 2009). Much like decomposition rate, the response of terrestrial enzymes to simulated $\mathrm{N}$ deposition ranges from enhancement to suppression (Carreiro and others 2000). However, resource trade-offs following allocation models are apparent. For example, simulated $\mathrm{N}$ enrichment can stimulate activity of enzymes that acquire C (Carreiro and others 2000) and P (Marklein and Houlton 2012), suggesting increased decomposition capacity and $\mathrm{P}$ demand, 
respectively. Consequently, variation in enzyme activity can explain the underlying stoichiometry of microbial metabolism, and enzymes are increasingly used in models designed to explain patterns of decomposition (for example, Moorhead and others 2012).

We used a long-term, whole-watershed experiment to determine whether terrestrial and aquatic systems follow the same trajectory in response to shifting nutrient availability. We hypothesized that $\mathrm{N}$ availability constrains decomposition rate and $\mathrm{N}$ enrichment would lead to increasing $\mathrm{P}$ limitation of decomposition. Because atmospheric $\mathrm{N}$ deposition shifts nutrient availability from organic matter decomposition to additional sources of available inorganic nutrient inputs to the system, we segregated these effects and compared them. We tested whether changes in decomposition rates were underlain by shifts in microbial metabolism and enzyme activity consistent with expectations of shifting resource availability to define a microbial mechanism behind altered decomposition. We hypothesized that $\mathrm{P}$ amendment would have stronger effects on aquatic decomposition, but that chronic $\mathrm{N}$ enrichment would lead to increased $\mathrm{P}$ limitation in both terrestrial and aquatic environments.

\section{Materials AND Methods}

\section{Site Description}

The Bear Brook Watershed in Maine (BBWM) is a long-term, paired watershed experiment composed of two gauged watersheds, one of which serves as a reference site (East Bear Brook, REF) and a second, contiguous watershed that has been treated bimonthly with $\mathrm{N}$ and acidifying chemicals (as $\left(\mathrm{NH}_{4}\right)_{2} \mathrm{SO}_{4}$ ) from 1989 to 2016 (West Bear Brook, TRT) (Norton and others 2010). The bedrock is quartzite and meta-pelite, intruded by dikes of granite. The soils, developed from till, are podzols (coarse, loamy, mixed, frigid typic Haplorthods). Vegetation includes American beech (Fagus grandifolia), maple (Acer spp.) and birch (Betula spp.) at lower elevations and spruce-fir-hemlock (Picea spp., Abies spp., Tsuga spp.) forest in upper elevations. The streams draining each watershed are first order and consist of steep channels of alternating riffles, pools and debris dams (see Chadwick and Huryn 2003 for detailed description). During 20082009, the duration of our experiments reported here, most vegetation in the treatment watershed had become enriched with $\mathrm{N}$ (Elvir and others 2010). Soils responded to treatments by accumu- lating $\mathrm{N}$ and $\mathrm{S}$, mobilizing $\mathrm{Al}$ and being depleted in exchangeable base cations, primarily Ca (Fernandez and others 2003; Norton and others 2010; Patel and others 2019). Stream water in the treatment catchment had seasonally high concentration of $\mathrm{NO}_{3}{ }^{-}(\sim 250 \mu \mathrm{g} \mathrm{N} / \mathrm{l})$ compared to low, constant values $(<5 \mu \mathrm{g} \mathrm{N} / \mathrm{l})$ in the reference stream (Navrátil and others 2010). The stream water in both streams was acidic but more so in the TRT watershed $(\mathrm{pH} \sim 5.2)$ than in the REF watershed $(\mathrm{pH}$ 5.5). Dissolved P concentrations were typically $3 \mu \mathrm{g} \mathrm{P} / \mathrm{l}$ in both streams (Reinhardt and others 2004). Total P commonly exceeded $100 \mu \mathrm{g} P / \mathrm{l}$ at high flow in the treated watershed; most of this total $\mathrm{P}$ was adsorbed to amorphous $\mathrm{Al}(\mathrm{OH})_{3}$ leached from the soil and precipitated in the stream.

\section{Experimental Design}

To address effects of altered leaf chemistry and altered environmental chemistry caused by the longterm $\mathrm{N}$ treatment at BBWM, we used a reciprocal design in which leaves sourced from each watershed were incubated in terrestrial plots and the streams of both watersheds. To test for P limitation, and how it interacts with altered leaf and environmental chemistry, leaves were incubated under ambient conditions and experimentally elevated $\mathrm{P}$ availability in terrestrial plots and in reaches of the streams in each watershed. We use 'treatment' to refer to the experimental watershed $\mathrm{N}$ enrichment and 'amendment' to refer to experimentally elevated $P$ we created in each watershed.

Leaves from American beech and sugar maple (Acer saccharum) were collected from the forest floor shortly after abscission of the REF and TRT catchments, yielding two leaf types (REF leaf, TRT leaf) for each species. We chose leaves of these species because they are common on the watersheds, and contrast in chemistry and decomposition rate, with beech typically having higher lignin and a slower decomposition rate than maple (Melillo and others 1982). Leaves of both species were $\mathrm{N}$-enriched in the TRT catchment (Table 1). Leaves were returned to the laboratory and air-dried for two weeks. Packs of each leaf type were constructed by placing about $4 \mathrm{~g}$ of dried leaves into plastic net bags $(1-\mathrm{cm}$ mesh). Sets of bags were created by joining one bag of each of the four leaf types with a plastic tie. The sets were transported to the field for deployment on September 23, 2008; four extra sets were returned to the laboratory and processed to determine handling loss, a conversion factor for initial air-dry mass to ash-free dry mass (AFDM) and initial leaf chemistry. 
Table 1. Initial Carbon, Nitrogen and Phosphorus Concentration of Maple and Beech Leaves Collected from the Reference (REF) and Treatment (TRT) Watersheds

\begin{tabular}{llllrrr}
\hline Leaf type & C (\%) & N (\%) & P (mg/kg) & C:N & C:P & N:P \\
\hline REF maple & $47.4(0.3)$ & $0.52(0.00)$ & $160(9)$ & $106(1)$ & $7670(360)$ & $72(4)$ \\
TRT maple & $47.1(0.4)$ & $0.70(0.01)$ & $192(9)$ & $78(2)$ & $6357(347)$ & $81(3)$ \\
REF beech & $48.2(0.2)$ & $0.75(0.04)$ & $212(26)$ & $75(4)$ & $6050(724)$ & $80(6)$ \\
TRT beech & $48.4(0.2)$ & $0.86(0.04)$ & $234(19)$ & $66(3)$ & $5406(456)$ & $82(4)$
\end{tabular}

Values are means $(n=3)$ with standard errors in parentheses. Concentrations are per unit ash-free dry mass. Ratios are molar.

In the REF and TRT streams, two contiguous 40$\mathrm{m}$ reaches were established. The upstream reach was maintained under ambient conditions, while the downstream reach was amended with $\mathrm{P}$ for 63 days. Phosphorus was added at the top $(0 \mathrm{~m})$ of the amended reaches as $\mathrm{KH}_{2} \mathrm{PO}_{4}$ to a target of $150 \mu \mathrm{g} / \mathrm{l}$ above ambient using a battery-powered fluid metering pump (FMI QBG, Fluid Metering Inc.) to saturate $\mathrm{P}$ availability to microbes. Pump rates were held constant; thus, the magnitude of $\mathrm{P}$ enrichment varied over time with changing stream discharge. In each reach, multiple leaf bag sets were anchored to the stream bed at three stations located 10,20 and $30 \mathrm{~m}$ from the top of the reach. One set was collected from each station at 16, 35, 47 and 63 days after deployment and returned to the laboratory on ice for processing.

For terrestrial decomposition, leaves were deployed into three stations in the hardwood zone of each catchment. Each station was comprised of a $10 \mathrm{~m} \times 10 \mathrm{~m}$ area in which ten leaf pack sets were anchored to the forest floor at 2-m grid spacing. Sets of packs in each station were randomly assigned to ambient or $\mathrm{P}$ amendment conditions. Ambient sets were sprayed with distilled water, whereas $\mathrm{P}$-amended sets were sprayed with an equal volume of the mixture of $\mathrm{KH}_{2} \mathrm{PO}_{4}$ in distilled water. The water or $\mathrm{P}$ mixture was applied to a $0.25 \mathrm{~m} \times 0.25 \mathrm{~m}$ area encompassing each set using a hand-held sprayer twice each month except between late December and mid-April when snowpack covered the leaves. Phosphorus was applied at rate of $100 \mathrm{~kg} \mathrm{P} \mathrm{ha}^{-1} \mathrm{y}^{-1}$, a value in the range of enrichments used by others in decomposition experiments (67-150 $\mathrm{kg} \mathrm{P} \mathrm{ha}^{-1} \mathrm{y}^{-1}$; (McGroddy and others 2004; Cleveland and others 2006; Hobbie 2008)). One control and one P-amended set were collected from each station after $35,233,268$, 328 and 399 days and returned to the laboratory on ice for processing. The duration of the sampling was targeted to yield a similar proportional mass loss as occurred in the stream experiment based on prior decomposition studies in the watersheds.

\section{Leaf and Water Chemistry}

Initial leaf $\mathrm{C}, \mathrm{N}$ and $\mathrm{P}$ concentrations were determined from packs used for handling loss and on leaves from the final collection date. Total $\mathrm{C}$ and $\mathrm{N}$ concentration of leaves was measured by combustion on a LECO CN-2000 analyzer (LECO Corporation, St-Joseph, MI). Leaf $\mathrm{P}$ concentration was determined by ICP-AES (IRIS-1000 Thermo Fisher Scientific, Waltham, MA) after ashing leaves and dissolving the ash in $\mathrm{HCl}$. Elemental concentration was expressed as \% dry mass. Stream water samples were collected at the top and bottom of each reach approximately twice each week during the experiment. Water samples were filtered (Whatman $\mathrm{GF} / \mathrm{F}, 0.8 \mu \mathrm{m}$ ) in the field, frozen and later analyzed for $\mathrm{NH}_{4}{ }^{+}, \mathrm{NO}_{3}{ }^{-}$and soluble reactive phosphorus (SRP) concentrations using a Lachat Quikchem 8500 analyzer (Hach company, Loveland, CO USA) following standard methods (Rice and Bridgewater 2012).

\section{Leaf Mass Loss}

In the laboratory, packs were opened and pieces of multiple leaves were cut, avoiding large veins and removed for measurement of microbial respiration and enzyme activity. The remainder of the pack was frozen until processing for mass loss. Packs were later thawed, rinsed over a $1-\mathrm{mm}$ sieve and sorted by hand to separate leaves from debris. The leaves were dried at $60{ }^{\circ} \mathrm{C}$ for $48 \mathrm{~h}$, weighed, combusted at $500{ }^{\circ} \mathrm{C}$, wetted with distilled water, dried at $60{ }^{\circ} \mathrm{C}$ and weighed. Leaf pieces used in microbial assays were similarly processed after use in assays. Ash-free dry mass (AFDM) of leaves was calculated as the difference between dry mass and ash remaining after combustion. The proportion of leaf mass remaining in each pack, including that used for microbial assays, was determined as the difference between initial AFDM and AFDM remaining on each collection date with correction for handling loss. Decomposition rates of terrestrial leaves were calculated from regression of the nat- 
ural $\log (\mathrm{ln})$ of proportion AFDM remaining over time $\left(\mathrm{R}^{2}\right.$ on regressions averaged 0.86 ; range $=$ 0.68-0.98). We calculated decomposition rates of stream leaf decomposition as the change from initial to final mass on the last date because of the shorter time frame and relatively small mass loss.

\section{Microbial Respiration}

We measured rates of respiration as an indicator of microbial metabolic activity contributing to decomposition. We interpolated respiration data from each collection date to calculate and estimate the 'total' microbial respiration that reflected changes over time. Rates of microbial respiration on leaves from the streams were determined by oxygen consumption in sealed vials on each collection date. Approximately $3 \mathrm{~g}$ wet mass of leaves from each pack was sealed in $26-\mathrm{ml}$ serum vials containing water at $100 \%$ oxygen saturation from their representative stream reach and incubated at $10{ }^{\circ} \mathrm{C}$ for 6 to $10 \mathrm{~h}$ with gentle stirring. Respiration rates on the leaf pieces were determined as differences between dissolved oxygen concentrations in the vials containing leaves and that in control vials that contained only stream water over the incubation period. Dissolved oxygen concentration was measured with an electronic meter (HQ40D with LDO probe, Hach Company). Preliminary trials were used to select incubation times that yielded linear rates of oxygen consumption.

For terrestrial leaves, rates of microbial respiration on each collection date were measured using a Gilson differential respirometer. For each leaf pack, approximately $0.25 \mathrm{~g}$ wet mass of leaves was placed in 25-ml Warburg vials. All leaves were moistened with $1.0 \mathrm{ml}$ of water from the REF stream to standardize leaf moisture. The stream water may have added some $\mathrm{N}$ and $\mathrm{P}$, but dissolved concentrations in the REF stream are very low (Table 1), so this was likely negligible. Vials were incubated for approximately $2 \mathrm{~h}$, and oxygen consumption was measured by volume change in the vials. Volumetric oxygen consumption was converted to mass using the ideal gas law.

\section{Microbial Enzymes}

We assayed potential activity of four extracellular enzymes associated with acquisition of $C(\beta-1,4-$ glucosidase, BG), $\mathrm{P}$ (acid phosphatase, AP) and $\mathrm{N}$ (leucine aminopeptidase, LAP and n-acetylglucosaminidase, NAG) on the final collection date. We note that LAP and NAG can also be involved in
C acquisition (Mori 2020). Enzyme activity was assayed using methylumbelliferone-labeled substrates (Enzyme/Substrate: BG /4-MUF- $\beta$-D glucoside, phosphatase/4-MUF-phosphate, NAG/4MUF-N-acetyl- $\beta$-glucosaminide) or methylcoumarin-labeled substrate (LAP/L-Leucine 7amido-4-methylcoumarin). Approximately $2 \mathrm{~g}$ wet mass of leaves was homogenized in $30 \mathrm{ml}$ of $50 \mathrm{mM}$ acetate buffer that was adjusted to $\mathrm{pH}$ 5.0. Two hundred microliters of the leaf slurry was added to each of 96-well microplates. Fifty microliters of a $200 \mu \mathrm{M}$ substrate solution was added to each well, and fluorescence was measured at $25^{\circ} \mathrm{C}$ using a microplate fluorometer (Fluoroskan Ascent FL, Thermo Fisher Scientific, Inc.). Reference methylumbelliferone or methylcoumarin standards and controls for particle quench and sample and substrate fluorescence were run on each plate. A series of test runs was used to establish incubation times that yielded linear increases in fluorescence over time and substrate concentrations that saturated enzyme kinetics. Enzymatic rates were expressed per unit dry mass of leaves.

\section{Data Analysis}

Initial chemistry of the leaves sourced from the reference and treatment watersheds was compared using t tests. We used linear models to examine the response of leaf decomposition rates, microbial respiration and enzyme activities to $\mathrm{P}$ amendment, incubation watershed, leaf watershed source, leaf species and habitat (terrestrial or stream) using the $\operatorname{lm}$ () function in $\mathrm{R}$ ( $\mathrm{R}$ Core Team 2021). We first fitted a model specified as response $\sim$ phosphorus *watershed*source*species + habitat:phosphorus to determine whether the terrestrial and stream habitats differed in response to phosphorus amendment (that is, significant habitat:phosphorus interaction term). When habitat:phosphorus interactions were apparent, we split the data and used separate models, specified as response $\sim$ phosphorus*watershed*source*species, for terrestrial and stream habitats. Our design is inherently pseudoreplicated as we had only one reference watershed and one treated watershed. However, our design permits consideration of 26 years of combined terrestrial and stream treatment that is neither easily replicated nor reproducible with smaller scale experiments. Model residuals were checked and data were $\log 10$ transformed, as needed, to meet assumptions of the linear models. All statistical analyses were performed in R v4.1.0 ( $\mathrm{R}$ Core Team 2020). 


\section{Results}

\section{Leaf and Stream Chemistry}

Maple leaves from the treated watershed had 34\% higher initial $\mathrm{N}$ concentration $(P<0.001)$ and a $26 \%$ lower C:N ratio $(P<0.001)$ than maple leaves from the reference watershed (Table 1). Initial phosphorus concentration $(P=0.063)$ and $\mathrm{C}: \mathrm{P}(P=0.059)$ were similar in maple leaves from the two watersheds. Beech leaves from the two watersheds did not differ in their initial $\mathrm{C}, \mathrm{N}$ and $\mathrm{P}$ concentration or elemental ratios (Table $\mathrm{l}$, $P>0.103)$. By the end of the experiment, leaves incubated in the TRT stream had $13-60 \%$ higher N than leaves in the REF stream (Table S1). Phosphorus amendment increased leaf $\mathrm{P}$ concentration by about $160 \%$ in the REF stream and about $820 \%$ in the TRT stream. There were no consistent differences in $\mathrm{N}$ of terrestrial leaves between the watersheds after incubation (Table S2). P amendment increased leaf P concentration by $120-280 \%$ on leaves in terrestrial plots with no consistent difference between watersheds.

Nitrate concentration in the stream water was, on average, two orders of magnitude higher in the TRT stream than the REF stream during the experiment (Table 2). Ammonium concentration was low and similar among the four stream reaches. Experimental addition of P elevated SRP more than 50-fold in the downstream reaches of the two streams compared to the low, similar concentrations in the upstream reference reaches $(\sim 3 \mu \mathrm{g}$ P/l). The mean DIN:SRP ratios among the four stream reaches spanned four orders of magnitude from 0.2 to 202 .

\section{Decomposition Rate}

Total mass loss ranged from 30 to $65 \%$ for terrestrial leaves and 3 to $52 \%$ for stream leaves. Decomposition rates responded differently to $\mathrm{P}$ amendment in terrestrial and stream habitats (P:habitat $P<<0.001 ;$ Table S3). In terrestrial plots, there was no difference between watersheds $(P=0.252)$ and no effect of $\mathrm{P}$ amendment $(P=0.460)$ on decomposition rate (Figure 1A; Table S4). There was a significant leaf source effect $(P=0.001)$, but this differed by species (source $x$ species $P=0.003$ ). Beech leaves sourced from the TRT watershed decayed about $20 \%$ faster than leaves from the REF watershed, but there was no clear difference for maple (Figure 1A). In streams, the effect of $\mathrm{P}$ amendment differed between watersheds $(P \times$ watershed $P=0.005$; Table S5). In particular, $\mathrm{P}$ amendment accelerated decomposition rate by $17-180 \%$ in the N-rich TRT stream but had little effect in the N-poor REF stream (Figure 1B). In contrast to the terrestrial habitat, there was no leaf source effect $(P=0.251)$ on leaf decomposition in the streams.

\section{Microbial Respiration}

Microbial respiration rates also responded differently to $\mathrm{P}$ amendment in terrestrial and stream habitats (P:habitat $P<<0.001$; Table S6). In the terrestrial habitat there was little evidence of an effect of $\mathrm{P}$ amendment on respiration $(P=0.046$; Table S7; Figure 2A) nor were there differences related to incubation watershed $(P=0.540)$ or leaf source $(P=0.692)$. In contrast, phosphorus amendment influenced microbial respiration in streams, but the effect depended on the watershed (P $\times$ watershed $P<0.001$; Table S8). As was the case for decomposition rate, $\mathrm{P}$ amendment increased respiration rate in the TRT stream by 33$73 \%$ but had little effect in the REF stream (Figure 2B). Microbial respiration rates were higher (roughly double or more) in the TRT watershed than in the REF watershed $(P<<0.001)$. Leaves sourced from the TRT watershed also tended to have higher respiration rates than leaves from the REF watershed $(P=0.011)$, but the difference was small compared to the effect of $\mathrm{P}$ and leaf source (Figure 2B).

Table 2. Dissolved Inorganic Nitrogen and Phosphorus Concentrations and Ratio in the Stream Water of the Upstream Ambient (amb) and Downstream P Enriched (+ P) Reaches of the Streams Draining the Reference (REF) and Treatment (TRT) Watersheds

\begin{tabular}{llcrr}
\hline Reach & $\mathrm{NH}_{4}{ }^{+}(\mu \mathrm{g} \mathrm{N} / \mathrm{l})$ & $\mathrm{NO}_{3}{ }^{-}(\mu \mathrm{g} \mathrm{N} / \mathrm{l})$ & SRP $(\mu \mathrm{g} \mathrm{P} / \mathrm{l})$ & DIN:SRP (molar) \\
\hline REF amb & $7(<2-14)$ & $1(<1-2)$ & $3(<1-6)$ & $8.4(3-28)$ \\
$\mathrm{REF}+\mathrm{P}$ & $6(<2-13)$ & $1(<1-2)$ & $221(9-597)$ & $0.2(0.01-3)$ \\
$\mathrm{TRT}$ amb & $7(<2-13)$ & $126(3-395)$ & $3(<1-7)$ & $202.0(12-1057)$ \\
TRT + P & $7(<2-15)$ & $126(3-389)$ & $138(4-405)$ & $13.7(0.11-198)$
\end{tabular}

Values are means of 17 dates with ranges in parentheses. DIN $=$ dissolved inorganic nitrogen $\left(\mathrm{NH}_{4}^{+}+\mathrm{NO}_{3}{ }^{-}\right) . S R P=$ soluble reactive phosphorus. 


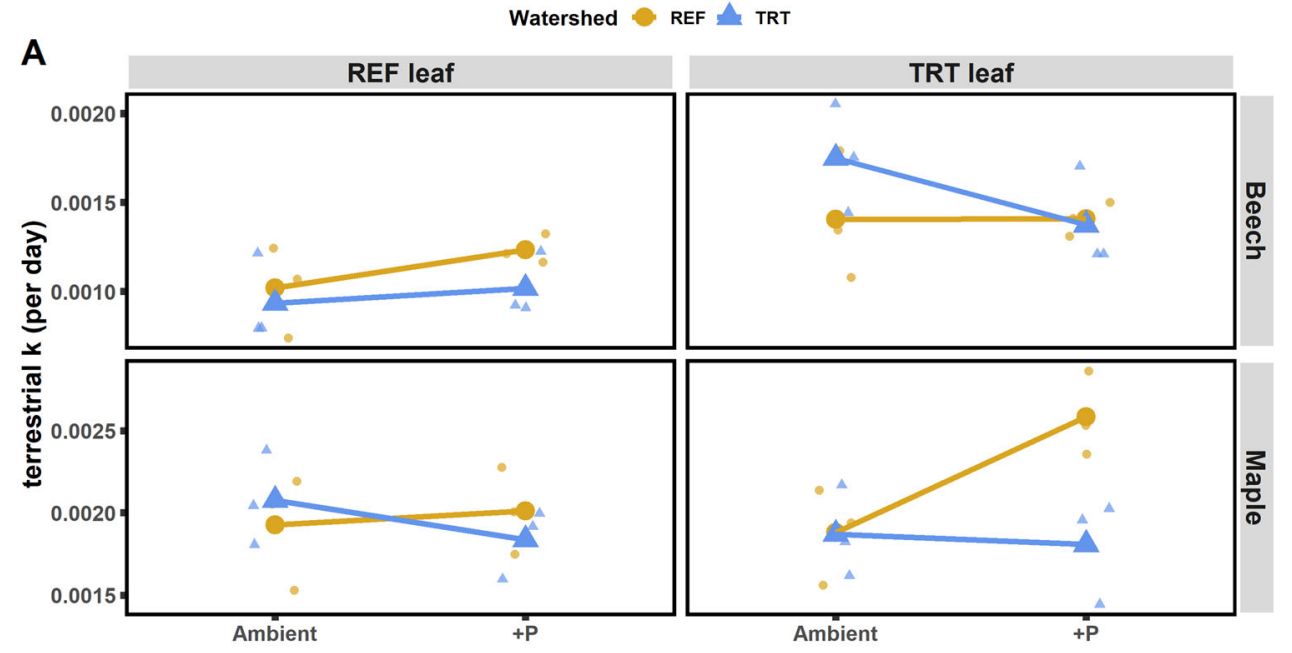

B
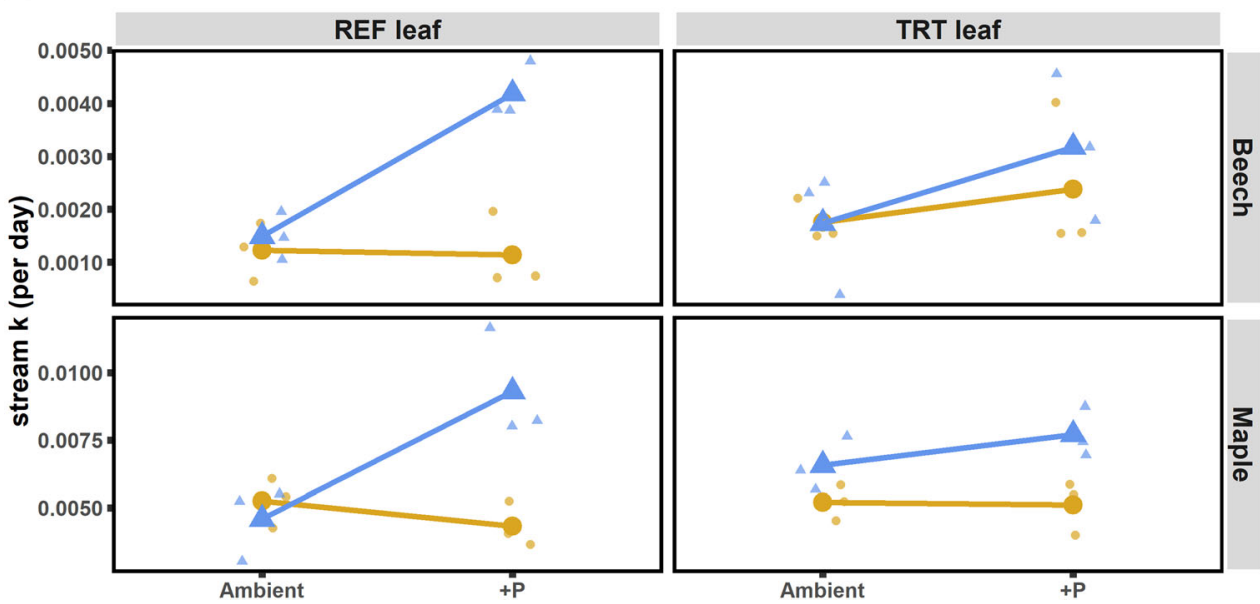

Figure 1. Leaf decomposition rates $(\mathrm{k})$ in the terrestrial $(\mathbf{A})$ and stream $(\mathbf{B})$ environment in the reference (REF) and treated (TRT) watersheds under ambient and elevated P. Decomposition rates of leaves originating from each watershed (REF leaf, TRT leaf) are shown. Small symbols are raw data and large symbols are means.

\section{Enzymes}

The activity of all enzymes responded differently to $\mathrm{P}$ amendment in terrestrial and stream habitats (P:habitat $P<<0.001$; Tables S9, S12 and S15). Activity of BG on terrestrial leaves was unresponsive to $\mathrm{P}$ amendment $(P=0.099)$ and similar in both watersheds $(P=0.588)$ and on leaves sourced from the different watersheds $(P=0.559$; Table S10; Figure 3A). In streams, BG activity was influenced by $\mathrm{P}$ amendment $(P=0.008)$ and incubation watershed $(P<<0.001)$, but unresponsive to change in leaf source $(P=0.139$; Table S11). Amendment with P tended to increase BG activity, but the effect was small (Figure 3B). Activity of BG was consistently higher ( twofold) in the TRT stream than in the REF stream (Fig- ure 3B) for both species under ambient or elevated $\mathrm{P}$ availability (Figure 3B).

Amendment with $\mathrm{P}$ reduced AP activity on terrestrial leaves by up to $80 \% \quad(P<<0.001$; Table S13) and the effect was the same in both watersheds and for both species regardless of the watershed source (Figure 4A). There was little evidence that incubation watershed $(P=0.044)$ or leaf source $(P=0.181)$ had much effect on AP activity on terrestrial leaves. In streams, the effect of $\mathrm{P}$ depended on the watershed $(P \times$ watershed $P<<0.001$; Table S14). In particular, AP activity was higher in the TRT watershed streams under ambient conditions and it declined to levels similar to that in the REF stream when amended with $\mathrm{P}$ (Figure 4B). Amendment with $\mathrm{P}$ reduced AP activity in the REF stream, but the change was 

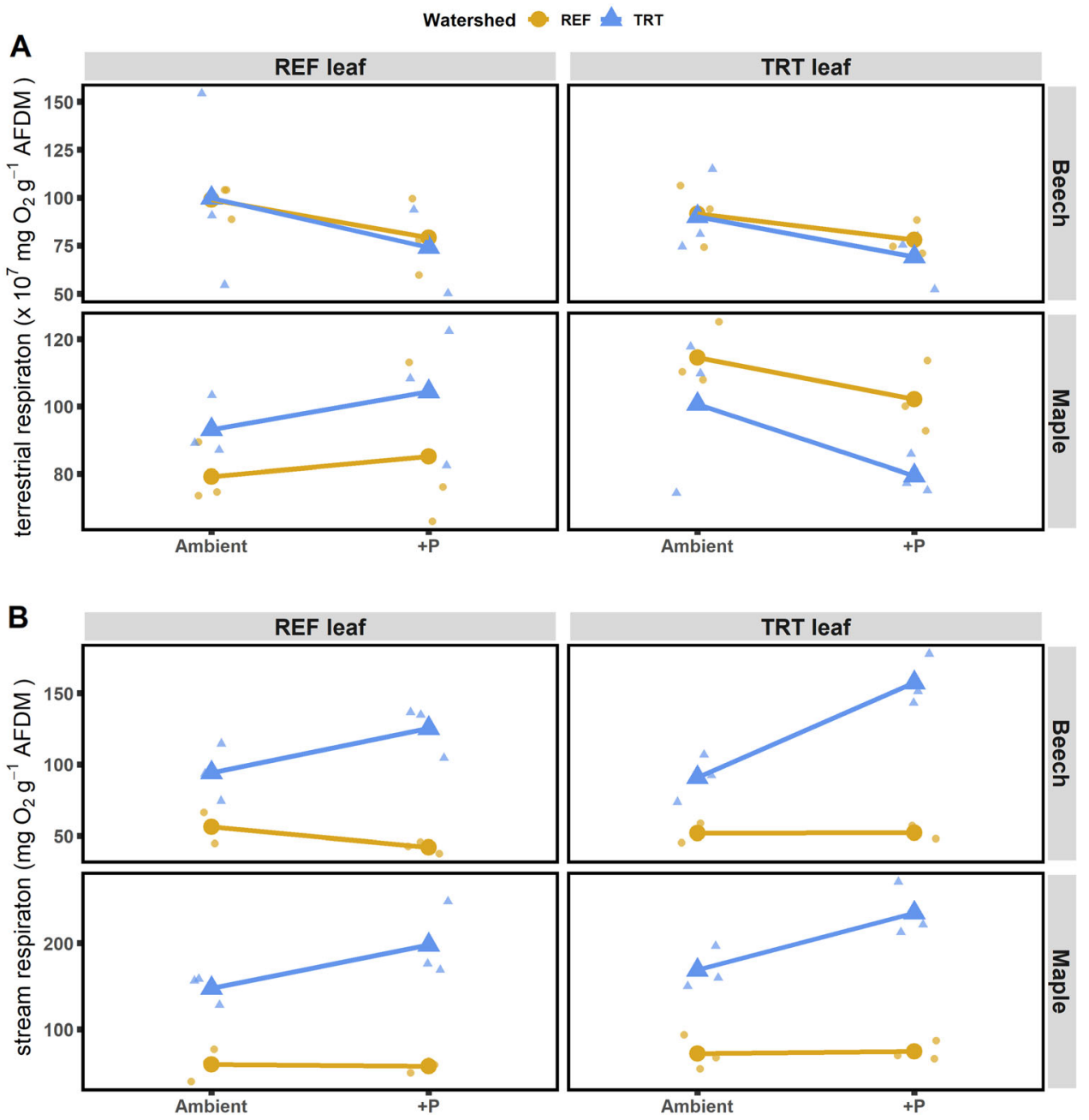

Figure 2. Microbial respiration rates in the terrestrial $(\mathbf{A})$ and stream $(\mathbf{B})$ environment in the reference (REF) and treated (TRT) watersheds under ambient and elevated P. Rates on leaves originating from each watershed (REF leaf, TRT leaf) are shown. Small symbols are raw data and large symbols are means.

much smaller than in the N-rich TRT stream (Figure $4 \mathrm{~B})$. We also found differences by leaf source $(P<0.001)$ and an interaction between leaf source and $\mathrm{P}$ amendment $(P=0.035$; Table S9). Activity of AP tended to be higher on the N-enriched leaves sourced from the TRT watershed, and the effect of $\mathrm{P}$ amendment was stronger on TRT leaves (Figure 4B).

Response of $\mathrm{N}$-acquiring enzymes in the terrestrial habitat was largely unresponsive to $\mathrm{P}$ amendment $\quad(P=0.529)$, incubation watershed $(P=0.326)$ or change in leaf source $(P=0.307$; Table S16, Figure 5A). In streams, LAP + NAG was consistently higher $(P<<0.001$, Table S17) by $40-100 \%$ in the TRT stream than in the REF stream. Amendment with P influenced activity, but it interacted with leaf source $(P<0.001)$. Amendment increased LAP + NAG activity on leaves from the TRT watershed but not on leaves from the REF watershed (Figure 5B).

\section{Discussion}

Anthropogenic supply of $\mathrm{N}$ can drive terrestrial and aquatic systems toward $\mathrm{P}$ limitation, a phenomenon typically examined for primary producers (Elser and others 2009; Vitousek and others 2010). Because decomposition is sensitive to nutrient availability and follows general stoichiometric theory we expected shifting nutrient limitation in response to long-term $\mathrm{N}$ fertilization (Mooshammer and others 2012). In our study, terrestrial and aquatic decomposition displayed divergent responses to chronic $\mathrm{N}$ and acute $\mathrm{P}$ experimental enrichment. The effect of the longterm $\mathrm{N}$ enrichment on terrestrial decomposition 

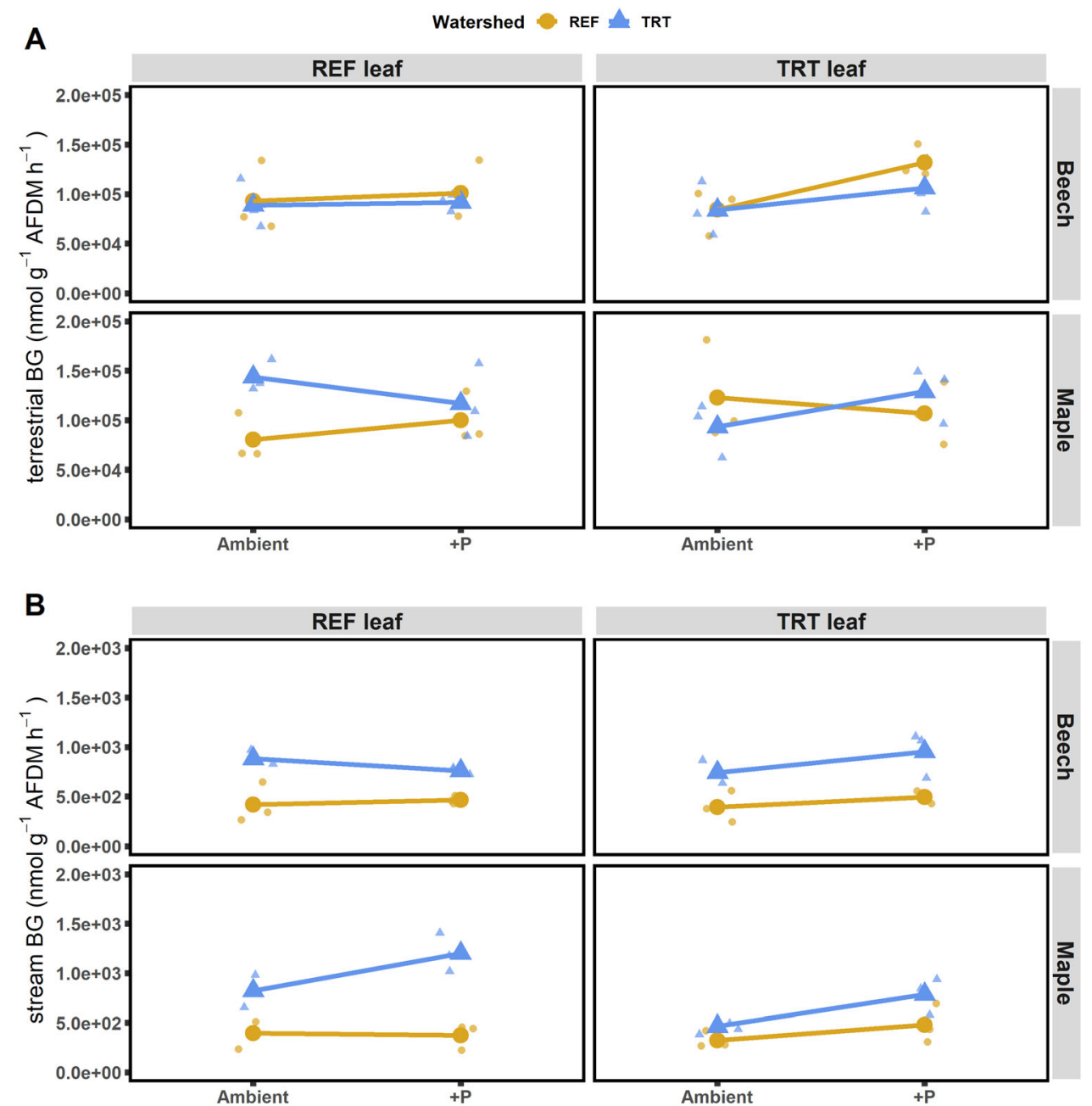

Figure 3. BG activity on leaves in the terrestrial $(\mathbf{A})$ and stream $(\mathbf{B})$ environments in the reference $(\mathrm{REF})$ and treated (TRT) watersheds under ambient and elevated P. Activity on leaves originating from each watershed (REF leaf, TRT leaf) is shown. Small symbols are raw data and large symbols are means.

was small and manifested largely through alteration in leaf chemistry and decomposition did not shift to P limitation in the $\mathrm{N}$-enriched watershed. In stark contrast, in streams leaf chemistry played a minor role and watershed $\mathrm{N}$ enrichment induced $\mathrm{P}$ limitation.

The response pattern of stream decomposition among the four experimental stream reaches was indicative of co-limitation by $\mathrm{N}$ and $\mathrm{P}$ under ambient conditions (that is, $\mathrm{N}$ and $\mathrm{P}$ together increased decomposition). This result mirrors patterns observed in other studies that have manipulated $\mathrm{N}$ and $\mathrm{P}$ at smaller spatial and shorter temporal scales. For example, $\mathrm{N}$ and $\mathrm{P}$ enrichment of stream reaches for several years (Rosemond and others 2015) and in stream mesocosms for a few months (Kominoski and others 2015) has shown co-limitation of $\mathrm{N}$ and $\mathrm{P}$ with several litter types in forested watersheds. The enrichment of stream water and leaves with $\mathrm{N}$ (TRT watershed) did not alter decomposition rates at BBWM, a result also observed by (Chadwick and Huryn 2003) in a prior study of the same streams. It did, apparently, saturate $\mathrm{N}$ demand and switch decomposition to $\mathrm{P}$ limitation as evident in the large increase in decomposition rates of beech and maple in the treatment streams augmented with $\mathrm{P}$. The concentration of dissolved inorganic $\mathrm{N}$ in the TRT stream $(\sim 190 \mu \mathrm{g} \mathrm{N} / \mathrm{l})$ was within the range $(\sim 50$ $520 \mu \mathrm{g} / \mathrm{l}$ ) found to saturate $\mathrm{N}$ limitation in other studies of stream litter decomposition (Kominoski and others 2015).

The effect of chronic experimental watershed $\mathrm{N}$ enrichment on streams was manifest largely through altered water chemistry as the relatively $\mathrm{N}$-rich maple leaves from the treated watershed 


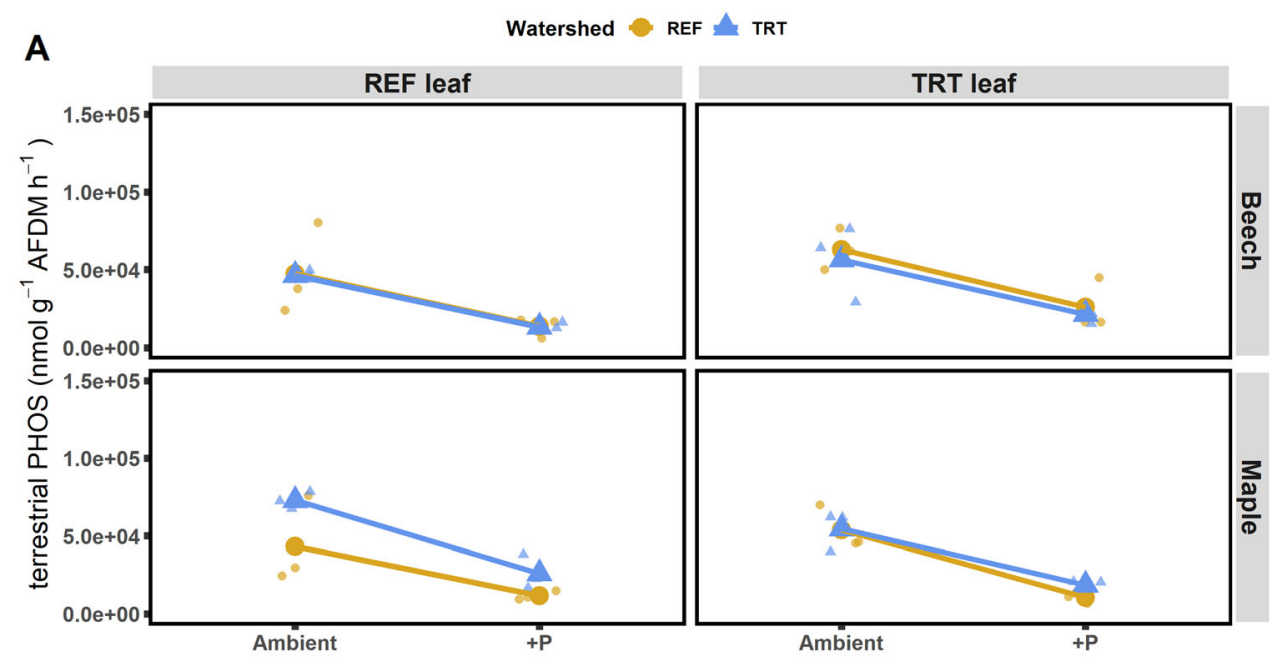

B

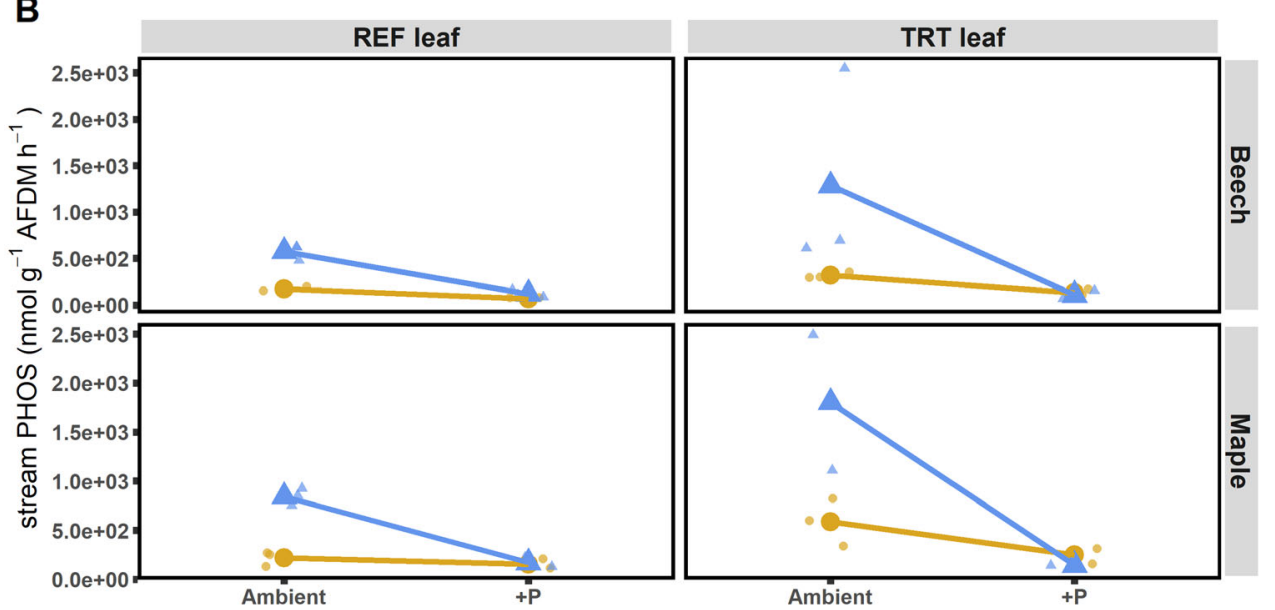

Figure 4. AP activity on leaves in the terrestrial $(\mathbf{A})$ and stream $(\mathbf{B})$ environments in the reference (REF) and treated (TRT) watersheds under ambient and elevated P. Activity on leaves originating from each watershed (REF leaf, TRT leaf) is shown. Small symbols are raw data and large symbols are means.

decayed at the same rate as leaves from the reference watershed. Leaf chemistry can influence decomposition rate in streams (Webster and Benfield 1986), but the change in chemistry of recently abscised leaves at BBWM was apparently insufficient to influence decomposition rate. Leaf chemistry also had little influence on the response of decomposition to changes in stream water chemistry. While stream water nutrient enrichment can have stronger effects on leaves with lower nutrient content (Kominoski and others 2015), maple and beech leaves, which differed in decomposition rate and initial chemistry, responded similarly to stream $\mathrm{N}$ and $\mathrm{P}$ enrichment in our experiment.

The patterns in decomposition we observed in streams were underlain by consistent microbial responses. Microbial respiration rates were higher in the $\mathrm{N}$-enriched TRT stream than in the REF stream and acute amendment with $\mathrm{P}$ further increased respiration. While microbial activity was spurred by stream water $\mathrm{N}$ enrichment, it was insufficient to alter decomposition rate. Decomposition is driven by enzymes and the patterns we observed were consistent with predictions from resource allocation models (Sinsabaugh and Moorhead 1994). This was evident as higher allocation toward C-acquiring enzymes as a response to $\mathrm{P}$ amendment, but only under high $\mathrm{N}$ availability.

Terrestrial decomposition rate is commonly positively associated with litter $\mathrm{N}$ availability, but experimental $\mathrm{N}$ enrichment leads to highly variable outcomes that encompass suppression, enhancement and no effect on decomposition (Knorr and others 2005). Normally, the effect of $\mathrm{N}$ fertilization is linked to substrate chemistry with $\mathrm{N}$-suppression of lignin degradation leading to reduced decomposi- 

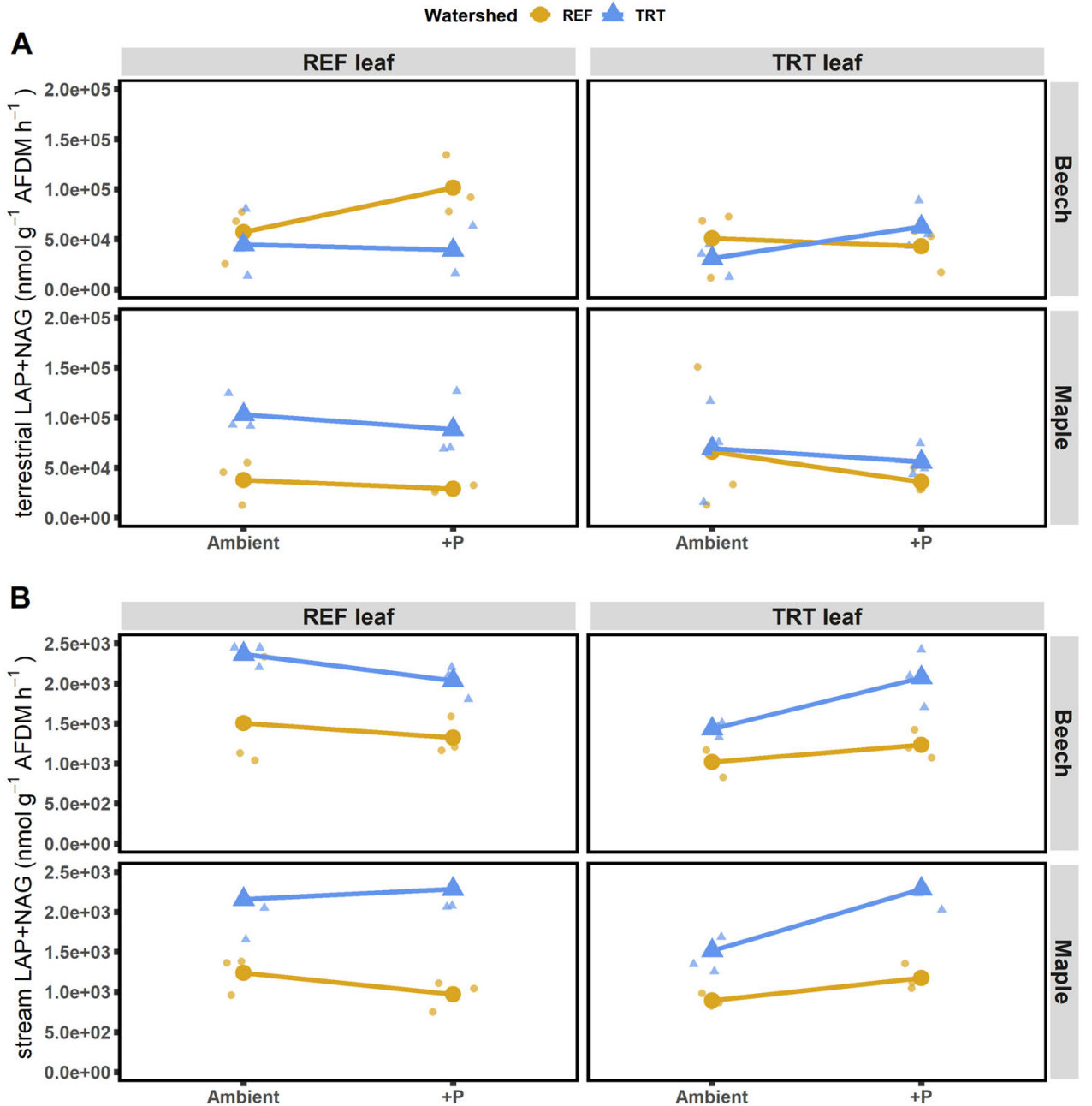

Figure 5. LAP + NAG activity on leaves in the terrestrial (A) and stream (B) environments in the reference (REF) and treated (TRT) watersheds under ambient and elevated P. Activity on leaves originating from each watershed (REF leaf, TRT leaf) is shown. Small symbols are raw data and large symbols are means.

tion, particularly for high-lignin substrates and in late stages of decomposition (Hobbie 2008). Our study focused on early stages of decomposition when we expected $\mathrm{N}$ fertilization to be most likely to stimulate decomposition (Hobbie 2008). However, neither beech nor maple decomposition rates under ambient conditions differed between the two watersheds despite 19 years of differences in $\mathrm{N}$ availability.

Phosphorus limitation of terrestrial decomposition has been shown in tropical sites (Vitousek and others 1993) and in the laboratory (Craine and others 2007), but generally has not been considered in temperate systems. In one of the few studies in temperate systems, DeForest (2019) found that P addition suppressed decomposition although the mechanism for this is unknown. Phosphorus clearly did not limit decomposition in our watersheds, even after nearly two decades of $\mathrm{N}$ enrichment suggesting that changes in stoichiometric balance between watershed $\mathrm{N}$ and $\mathrm{P}$ inputs to streams does not influence nutrient limitation patterns of terrestrial decomposition, in striking contrast to what occurs in streams.

We note that the TRT watershed $\mathrm{N}$ enrichment was accompanied by acidification that has altered an array of watershed characteristics (Norton and others 2010). Base cations had been depleted and soil $\mathrm{pH}$ had declined, but this does not appear to have influenced decomposition rate as we found similar rates in both watersheds. This may be because we examined early decomposition in the uppermost litter layer rather than in deeper soils where chemical change is greater. Acidification does not appear to have directly influenced decomposition in the streams as it typically suppresses decomposition rate (Simon and others 2009), but decomposition rate was similar between watersheds in the absence of $\mathrm{P}$ enrichment (our 
data and Chadwick and Huryn 2003). We suspect watershed acidification enhances $\mathrm{P}$ limitation in the TRT catchment streams by mobilizing $\mathrm{Al}$ to the stream where it precipitates and sequesters $\mathrm{P}$, also mobilized from the soil (Navrátil and others 2010). Mobilization of $\mathrm{P}$ in the rooting zone and increased uptake may explain the somewhat higher $\mathrm{P}$ concentration in beech and maple leaves (Table 1). In prior work we have found that $\mathrm{P}$ uptake is higher in the TRT stream and that $\mathrm{P}$ addition stimulates uptake of $\mathrm{N}$ in both streams (Simon and others 2010). In essence, acidification draws down $\mathrm{P}$ supply in the streams through adsorption of $\mathrm{PO}_{4}$ by $\mathrm{Al}(\mathrm{OH})_{3}$ in both streams, while $\mathrm{N}$ enrichment releases $\mathrm{N}$ limitation, amplifying the effect of atmospheric deposition on streams.

Why are terrestrial and stream responses to atmospheric $\mathrm{N}$ deposition so different? We suspect the answer at least partly stems from the most obvious difference between these ecosystem compartments, the availability of water. Water scarcity can reduce decomposition in terrestrial (Allison and others 2013) and stream (Chadwick and Huryn 2003) systems. Water availability may set the stage for differential responsiveness of terrestrial and stream systems to shifting nutrient availability by modulating microbial stress and the flux of exogenous nutrients to microbes.

Drying stress alters microbial function (Fierer and Schimel 2002) and moisture influences enzyme activity (Sardans and Peñuelas 2005), often with differing effects among enzymes. Consequently, water stress may limit capacity for enzyme allocation trade-offs that underlie decomposition response to shifting nutrient availability seen in streams. Notably, the loose litter layer which we simulated in our terrestrial plots is particularly prone to a high temporal variability in wetting and drying. Drying may have decoupled nutrient limitation and enzyme resource allocation (that is, adding P stimulated AP, but constrained capacity to increase BG and LAP/NAG that would drive increased decomposition). For example, Sardans and Peñuelas (2005) found drying led to reduced BG and peptidase, but not AP, activity in the terrestrial environment. Our results only hold for initial phases of decomposition in the loose litter layer, but mass loss during the 399 days of our experiment was consequential (that is, $\sim 30-65 \%$ mass loss in our terrestrial litter bags).

Water may also modulate how interactions between endogenous and exogenous nutrient availability influence decomposition. For example, microbial N mining (Moorhead and others 2012) may explain why increasing exogenous $\mathrm{N}$ supply inhibits decomposition in terrestrial systems. Essentially, increased $\mathrm{N}$ supply inhibits lignin degradation that typically is used to support acquisition of $\mathrm{N}$ from organic matter. It is possible that this phenomenon does not occur in streams where flowing water creates a continual flux of exogenous nutrients to microbes. To our knowledge nobody has examined mining in a stream context, highlighting the disconnect between how terrestrial and aquatic systems are typically studied. Our work suggests that a more holistic approach that expressly considers linked terrestrial and aquatic processes simultaneously will yield deeper insight into the impact of large-scale phenomena like air pollution.

\section{ACKNOWLEDGEMENTS}

This research was supported by grants from the National Science Foundation (DEB-1056692, DEB0841571, REU-1026142 and 11119709, and LTREB-DEB-0639902) and funding through the Maine Agricultural and Forest Experiment Station (MAFES). We thank the two anonymous reviewers for comments that improved this manuscript.

\section{FUNDING}

Open Access funding enabled and organized by CAUL and its Member Institutions.

\section{OPEN ACCESS}

This article is licensed under a Creative Commons Attribution 4.0 International License, which permits use, sharing, adaptation, distribution and reproduction in any medium or format, as long as you give appropriate credit to the original author(s) and the source, provide a link to the Creative Commons licence, and indicate if changes were made. The images or other third party material in this article are included in the article's Creative Commons licence, unless indicated otherwise in a credit line to the material. If material is not included in the article's Creative Commons licence and your intended use is not permitted by statutory regulation or exceeds the permitted use, you will need to obtain permission directly from the copyright holder. To view a copy of this licence, visit $h$ ttp://creativecommons.org/licenses/by/4.0/.

\section{REFERENCES}

Allison SD, Vitousek PM. 2005. Responses of extracellular enzymes to simple and complex nutrient inputs. Soil Biology and Biochemistry 37:937-944. 
Allison SD, Lu Y, Weihe C, Goulden ML, Martiny AC, Treseder KK, Martiny JBH. 2013. Microbial abundance and composition influence litter decomposition response to environmental change. Ecology 94:714-725.

Carreiro MM, Sinsabaugh RL, Repert DA, Parkhurst DF. 2000. Microbial enzyme shifts explain litter decay responses to simulated nitrogen deposition. Ecology 81:2359-2365.

Chadwick MA, Huryn AD. 2003. Effect of a whole-catchment N addition on stream detritus processing. Journal of the North American Benthological Society 22:194-206.

Cleveland CC, Reed SC, Townsend AR. 2006. Nutrient regulation of organic matter decomposition in a tropical rain forest. Ecology 87:492-503.

Craine JM, Morrow C, Fierer N. 2007. Microbial nitrogen limitation increases decomposition. Ecology 88:2105-2113.

Crowley KF, McNeil BE, Lovett GM, Canham CD, Driscoll CT, Rustad LE, Denny E, Hallett RA, Arthur MA, Boggs JL, Goodale CL, Kahl JS, McNulty SG, Ollinger SV, Pardo LH, Schaberg PG, Stoddard JL, Weand MP, Weathers KC. 2012. Do nutrient limitation patterns shift from nitrogen toward phosphorus with increasing nitrogen deposition across the northeastern United States? Ecosystems 15:940-957.

DeForest JL. 2019. Chronic phosphorus enrichment and elevated $\mathrm{pH}$ suppresses Quercus spp. leaf litter decomposition in a temperate forest. Soil Biology and Biochemistry 135:206-212.

Elser JJ, Andersen T, Baron JS, Bergström A-K, Jansson M, Kyle M, Nydick KR, Steger L, Hessen DO. 2009. Shifts in lake N: P STOICHIOMETRY AND NUTRIENT LIMITATION DRIVEN BY ATMOSPHERIC NITROGEN DEPosition. Science 326:835837.

Elser JJ, Bracken MES, Cleland EE, Gruner DS, Harpole WS, Hillebrand H, Ngai JT, Seabloom EW, Shurin JB, Smith JE. 2007. Global analysis of nitrogen and phosphorus limitation of primary producers in freshwater, marine and terrestrial ecosystems. Ecol Lett 10:1135-1142.

Elvir JA, Wiersma GB, Bethers S, Kenlan P. 2010. Effects of chronic ammonium sulfate treatment on the forest at the Bear Brook Watershed in Maine. Environ Monit Assess 171:129147.

Elwood JW, Newbold JD, Trimble AF, Stark RW. 1981. The limiting role of phosphorus in a woodland stream ecosystem: effects of $\mathrm{P}$ enrichment on leaf decomposition and primary producers. Ecology 62:146-158.

Fernandez IJ, Rustad LE, Norton SA, Kahl JS, Cosby BJ. 2003. Experimental acidification causes soil base-cation depletion at the Bear Brook Watershed in Maine. Soil Science Society of America Journal 67:1909-1919.

Ferreira V, Gulis V, Graça MAS. 2006. Whole-stream nitrate addition affects litter decomposition and associated fungi but not invertebrates. Oecologia 149:718-729.

Fierer N, Schimel JP. 2002. Effects of drying-rewetting frequency on soil carbon and nitrogen transformations. Soil Biology and Biochemistry 34:777-787.

Greenwood JL, Rosemond AD, Wallace JB, Cross WF, Weyers HS. 2007. Nutrients stimulate leaf breakdown rates and detritivore biomass: bottom-up effects via heterotrophic pathways. Oecologia 151:637-649.

Gress SE, Nichols TD, Northcraft CC, Peterjohn WT. 2007. Nutrient limitation in soils exhibiting differing nitrogen availabilities: what lies beyond nitrogen saturation? Ecology 88:119-130.
Grimm NB, Gergel SE, McDowell WH, Boyer EW, Dent CL, Groffman P, Hart SC, Harvey J, Johnston C, Mayorga E, McClain ME, Pinay G. 2003. Merging aquatic and terrestrial perspectives of nutrient biogeochemistry. Oecologia 137:485501.

Groffman PM, Fisk MC. 2011. Phosphate additions have no effect on microbial biomass and activity in a northern hardwood forest. Soil Biology and Biochemistry 43:2441-2449.

Hobbie SE. 2008. Nitrogen effects on decomposition: a five-year experiment in eight temperate sites. Ecology 89:2633-2644.

Knorr M, Frey SD, Curtis PS. 2005. Nitrogen additions and litter decomposition: a meta-analysis. Ecology 86:3252-3257.

Kominoski JS, Rosemond AD, Benstead JP, Gulis V, Maerz JC, Manning DWP. 2015. Low-to-moderate nitrogen and phosphorus concentrations accelerate microbially driven litter breakdown rates. Ecological Applications 25:856-865.

Marklein AR, Houlton BZ. 2012. Nitrogen inputs accelerate phosphorus cycling rates across a wide variety of terrestrial ecosystems. New Phytologist 193:696-704.

McGroddy ME, Silver WL, de Oliveira RC. 2004. The effect of phosphorus availability on decomposition dynamics in a seasonal lowland Amazonian forest. Ecosystems 7:172-179.

Melillo JM, Aber JD, Muratore JF. 1982. Nitrogen and lignin control of hardwood leaf litter decomposition dynamics. Ecology 63:621-626.

Moorhead DL, Lashermes G, Sinsabaugh RL. 2012. A theoretical model of $\mathrm{C}$ - and $\mathrm{N}$-acquiring exoenzyme activities, which balances microbial demands during decomposition. Soil Biology and Biochemistry 53:133-141.

Mooshammer M, Wanek W, Schnecker J, Wild B, Leitner S, Hofhansl F, Blöchl A, Hämmerle I, Frank AH, Fuchslueger L, Keiblinger KM, Zechmeister-Boltenstern S, Richter A. 2012 Stoichiometric controls of nitrogen and phosphorus cycling in decomposing beech leaf litter. Ecology 93:770-782.

Mori T. 2020. Does ecoenzymatic stoichiometry really determine microbial nutrient limitations? Soil Biology and Biochemistry 146:107816.

Navrátil T, Norton SA, Fernandez IJ, Nelson SJ. 2010. Twentyyear inter-annual trends and seasonal variations in precipitation and stream water chemistry at the Bear Brook Watershed in Maine, USA. Environ Monit Assess 171:23-45.

Norton SA, Fernandez IJ, Kahl JS, Rustad LE, Navrátil T, Almquist H. 2010. The evolution of the science of Bear Brook Watershed in Maine, USA. Environ Monit Assess 171:3-21.

Patel KF, Fernandez IJ, Nelson SJ, Gruselle M-C, Norton SA, Weiskittel AR. 2019. Forest N dynamics after 25 years of whole Watershed N enrichment: the Bear Brook Watershed in Maine. Soil Science Society of America Journal 83:S161S174.

R Core Team. 2021. R: A Language and Environment for Statistical Computing. R Foundation for Statistical Computing Available from http://www.r-project.org.

Perring MP, Hedin LO, Levin SA, McGroddy M, de Mazancourt C. 2008. Increased plant growth from nitrogen addition should conserve phosphorus in terrestrial ecosystems. Proceedings of the National Academy of Sciences 105:1971-1976.

Reinhardt RL, Norton SA, Handley M, Amirbahman A. 2004. Dynamics of $\mathrm{P}, \mathrm{Al}$, and $\mathrm{Fe}$ during high discharge episodic acidification at the Bear Brook Watershed in Maine, U.S.A. Water, Air, \& Soil Pollution: Focus 4:311-323. 
Rice EW, Bridgewater L. 2012. Standard methods for the examination of water and wastewater, 22nd edn. Washington, DC: American Public Health Association.

Rosemond AD, Benstead JP, Bumpers PM, Gulis V, Kominoski JS, Manning DWP, Suberkropp K, Wallace JB. 2015. Experimental nutrient additions accelerate terrestrial carbon loss from stream ecosystems. Science 347:1142-1145.

Sardans J, Peñuelas J. 2005. Drought decreases soil enzyme activity in a Mediterranean Quercus ilex L. forest. Soil Biology and Biochemistry 37:455-461.

Simon KS, Simon MA, Benfield EF. 2009. Variation in ecosystem function in Appalachian streams along an acidity gradient. Ecological Applications 19:1147-1160.

Simon KS, Chadwick MA, Huryn AD, Valett HM. 2010. Stream ecosystem response to chronic deposition of $\mathrm{N}$ and acid at the Bear Brook Watershed, Maine. Environ Monit Assess 171:8392.

Sinsabaugh RL, Moorhead DL. 1994. Resource allocation to extracellular enzyme production: A model for nitrogen and phosphorus control of litter decomposition. Soil Biology and Biochemistry 26:1305-1311.

Sinsabaugh RL, Hill BH, Follstad Shah JJ. 2009. Ecoenzymatic stoichiometry of microbial organic nutrient acquisition in soil and sediment. Nature 462:795-798.

Thomas R, Canham CD, Weathers KC, Goodale CL. 2010. Increased tree carbon storage in response to nitrogen deposition in the US. Nature Geosci 3:13-17.
Vadeboncoeur MA. 2010. Meta-analysis of fertilization experiments indicates multiple limiting nutrients in northeastern deciduous forests. Can J For Res 40:1766-1780.

Vitousek PM, Howarth RW. 1991. Nitrogen limitation on land and in the sea: how can it occur? Biogeochemistry 13:87-115.

Vitousek PM, Walker LR, Whiteaker LD, Matson PA. 1993. Nutrient limitations to plant growth during primary succession in Hawaii Volcanoes National Park. Biogeochemistry 23:197-215.

Vitousek PM, Aber JD, Howarth RW, Likens GE, Matson PA, Schindler DW, Schlesinger WH, Tilman DG. 1997. Human alteration of the global nitrogen cycle: sources and consequences. Ecological Applications 7:737-750.

Vitousek PM, Porder S, Houlton BZ, Chadwick OA. 2010. Terrestrial phosphorus limitation: mechanisms, implications, and nitrogen-phosphorus interactions. Ecological Applications 20:5-15.

Wagener SM, Oswood MW, Schimel JP. 1998. Rivers and soils: parallels in carbon and nutrient processing. BioScience 48:104-108.

Webster JR, Benfield EF. 1986. Vascular plant breakdown in freshwater ecosystems. Annual Review of Ecology and Systematics 17:567-594. 